\title{
Monoculture Maize (Zea mays L.) Cropped Under Conventional Tillage, No-tillage and N Fertilization: (I) Three Year Yield Performances
}

\author{
Vincenzo Tabaglio*, Carolina Gavazzi \\ Istituto di Agronomia, Genetica e Coltivazioni Erbacee, Università Cattolica del Sacro Cuore \\ Via Emilia Parmense 84, 29100 Piacenza, Italy
}

Received: 8 May 2009. Accepted: 7 September 2009.

\begin{abstract}
A three-year (2004-2006) field trial was carried out to compare two agricultural land management systems, in the Po Valley (Northern Italy). Conventional tillage and No-tillage (hereafter indicated as CT and NT, respectively) were compared for maize treated with three levels of nitrogen. The soil was a fine-loamy, mixed, mesic Ultic Haplustalf, that had been under processing tomato in the previous year. Experimental design was a split-plot with four replicates, with the management system as the main factor and nitrogen fertilization $\left(0,250\right.$ and $\left.300 \mathrm{~kg} \mathrm{~N} \mathrm{ha}^{-1} \mathrm{year}^{-1}\right)$ as the secondary factor. Cumulative 3-yr yields of grain and total biomass of NT maize plants were $8 \%$ lower than those obtained under CT management, but not significantly different. No N starter was distributed in the first conversion year, causing $17 \%$ less grain yield in the NT plots compared with the CT plots. The N fertilizing with 250 and $300 \mathrm{~kg} \mathrm{~N} \mathrm{ha}^{-1}$ year ${ }^{-1}$ determined statistically equal grain yields, demonstrating the waste of the extra $50 \mathrm{~kg} \mathrm{~N}$ at the $\mathrm{N}_{2}$ rate. Overall, the results for the three years indicate that on an Ultic Haplustalf conversion from a ploughed regime to mature NT conditions could be achieved over a relatively short period.
\end{abstract}

Key-words: no-tillage, conventional tillage, $\mathrm{N}$ fertilization, maize, Zea mays $\mathrm{L}$.

\section{Introduction}

Grain maize is a very important crop in Italy, where it is grown on more than a million hectares, about $90 \%$ of which is located in the Po Valley. Although the agronomic, economic and environmental advantages of no-tillage have been repeatedly presented and discussed worldwide (Phillips and Phillips, 1984; Sprague and Triplett, 1986; Baker et al., 1996; Uri, 1999), less than a thousand hectares are now managed using this soil management system in Italy (Sartori and Peruzzi, 1994; Tabaglio, 2007). The limited use of this technique is due to several factors: wrong choice of soil type, short-term experimental studies, and inadequate knowledge about the differences in herbicide treatments and fertilizers needed (Prasad and Power, 1991; Cannell and Hawes, 1994; Cassel and Wagger,
1996; Franzluebbers et al., 1999; Hamza and Anderson, 2005). Principally, however, the major obstacle has been the poor adaptability of farmers to the new principles of management that no-tillage requires.

In the Po Plain intensive cropping of continuous maize with excessive fertilization has caused environmental pollution especially as regards water (ARPAER, 2004), and maximal tillage has caused the depletion of soil resources.

Because agronomic research on no-tillage maize in the Po Valley (Northern Italy) is very scanty (Toderi and Bonari, 1986; Borin and Sartori, 1995), and has not fully investigated the suitability of various soils to the adoption of this technique, this field experiment was designed to evaluate no-tillage maize response on a less fer-

\footnotetext{
* Corresponding Author: Fax: +39 0523 599222. E-mail address: vincenzo.tabaglio@unicatt.it
} 
tile soil and without starter $\mathrm{N}$ as compared with a previous trial (Tabaglio and Gavazzi, 2006).

\section{Materials and methods}

During 2004-2006 an experimental trial was carried out at Terranova dei Passerini (LO, Po Valley, Northern Italy). The soil was a fine-loamy, mixed, mesic Ultic Haplustalf, (Soil Survey Staff, 1996), previously under processing tomato. The main physical and chemical properties of the soil at the beginning of the experiment are shown in Table 1.

Rainfall data for the 2004-2006 period are shown in Table 2 and compared with average climatological data.

The experimental design was a split-plot with four replicates, that was kept unchanged for the three years of the trial. The main factor was the soil management system (conventional tillage vs no-tillage, hereafter indicated as CT and NT, respectively), with the rate of applied nitrogen $\left(0,250\right.$ and $300 \mathrm{~kg} \mathrm{~N}^{-1}$ year $\left.^{-1}\right)$ as the secondary factor, for a total of 24 sub-plots. Each sub-plot was $4.5 \mathrm{~m}$ wide and $12 \mathrm{~m}$ long. It is widely known that during the transition from a ploughed regime to mature NT conditions, NT soils have a lower $\mathrm{N}$ availability compared with $\mathrm{CT}$ soils. This decrease has been estimated from 10 to $40 \mathrm{~kg} \mathrm{~N} \mathrm{ha}^{-1}$, depending on the crop and climatic conditions (Bakermans and DeWit, 1970; Davies and Cannell, 1975; Phillips et al., 1980; Bandel et al., 1984). Thus it is usual to supply a small additional amount of $\mathrm{N}$ to the NT plots ("N starter"), in order to level the outstart of the compared crops. However, in this experiment it was decided not to apply "N starter" to the NT plots, in contrast with our previous trial on maize (Tabaglio and Gavazzi, 2006), be- cause one of the aims of this study was to quantify the reduction in the yield and the number of years this decrease lasts. The fertilizer was top dressed twice, in equal quantities. The first application was immediately after plant emergence with 0,125 and $150 \mathrm{~kg} \mathrm{~N}^{-1}$, as $\mathrm{Ca}\left(\mathrm{NO}_{3}\right)_{2}$ $(15.5 \% \mathrm{~N})$; the second application was at the V6-V8 stage. The CT plots were ploughed to a depth of $30 \mathrm{~cm}$, and then harrowed twice with a rotating harrow $(15 \mathrm{~cm})$. The NT plots were direct-planted through the chopped residues of the previous crop. The NT plots were treated with Glyphosate before maize planting. In all years, the hybrid PR34N43, FAO 500 (Pioneer Hi-Bred Italia) was used, with a row spacing of $70 \mathrm{~cm}$. Seed density was 9.2 and 8.9 seeds $\mathrm{m}^{-2}$ for NT and CT, respectively. The higher density for NT was chosen to compensate for the difficulty of seedling emergence in NT soil (Ritchie and Baker, 2007). The NT plots were sown using a 4-row pneumatic planter (Gaspardo, Tandem 2); the CT plots were sown using a 4-row pneumatic precision planter (Gaspardo, SP250). When necessary, maize crop has been irrigated by flood technique. Maize yields were determined from a $16.8 \mathrm{~m}^{2}$ area of each plot. The plants were separated into grain, cobs and stover for mass determination. The following parameters were recorded: grain and total yield, grain and stover $\mathrm{N}$ concentration, grain and total $\mathrm{N}$ uptake, $\mathrm{N}$ apparent recovery. Analysis of variance was performed for statistical analysis of all data (MSTAT-C Software); the LSDs were calculated for $\mathrm{P} \leq 0.05$ level.

\section{Results and discussion}

The results for grain and total dry matter yield and their $\mathrm{N}$ uptake are presented for each year,

Table 1. Physical and chemical properties of the soil at the beginning of the experiment $(0-30 \mathrm{~cm}$ depth).

\begin{tabular}{lll}
\hline sand $(2-0.05 \mathrm{~mm})$ & $\mathrm{g} \mathrm{kg}^{-1}$ & 152 \\
silt $(0.05-0.002 \mathrm{~mm})$ & $\mathrm{g} \mathrm{kg}^{-1}$ & 601 \\
clay $(<0.002 \mathrm{~mm})$ & $\mathrm{g} \mathrm{kg}^{-1}$ & 247 \\
$\mathrm{pH}\left(\mathrm{CaCl}_{2}, 0.01 \mathrm{M}\right)$ & & 6.46 \\
organic matter (Walkley and Black) & $\mathrm{g} \mathrm{kg}^{-1}$ & 16.7 \\
total N (Kjeldahl) & $\mathrm{g} \mathrm{kg}^{-1}$ & 1.10 \\
available P (Na bicarbonate 0.5 M, pH 8.5) & $\mathrm{mg} \mathrm{kg}^{-1}$ & 24.3 \\
exchangeable K (Ba chloride, $\mathrm{pH} 8.1)$ & $\mathrm{mg} \mathrm{kg}^{-1}$ & 85.9 \\
cation exchangeable capacity (Ba chloride, $\mathrm{pH} \mathrm{8.1)}$ & $\mathrm{cmol}^{+} \mathrm{kg}^{-1}$ & 12.6 \\
electrical conductivity & $\mu \mathrm{H} \mathrm{cm}^{-1}$ & 112
\end{tabular}


Ital. J. Agron. / Riv. Agron., 2009, 3:61-67

Table 2. Annual and maize growing season rainfall as compared with average climatological data

\begin{tabular}{|c|c|c|c|c|c|c|}
\hline \multirow[t]{3}{*}{ Year } & \multicolumn{3}{|c|}{ Annual rainfall } & \multicolumn{3}{|c|}{ April to September } \\
\hline & \multirow{2}{*}{$\frac{\text { amount }}{\mathrm{mm}}$} & \multicolumn{2}{|c|}{ deviation } & \multirow{2}{*}{$\frac{\text { amount }}{\mathrm{mm}}$} & \multicolumn{2}{|c|}{ deviation } \\
\hline & & $\mathrm{mm}$ & $\%$ & & $\mathrm{~mm}$ & $\%$ \\
\hline 2004 & 758 & +20 & +3 & 280 & -99 & -26 \\
\hline 2005 & 874 & +136 & +18 & 473 & +94 & +25 \\
\hline 2006 & 658 & -80 & -11 & 378 & -1 & 0 \\
\hline 1987-2006 mean & 738 & & & 379 & & \\
\hline
\end{tabular}

in order to compare annual performance against the specific meteorological conditions. Finally, to compare the two management systems overall, maize performance over the 3-year period was considered.

Year 2004

During 2004 rainfall was near normal up to the first ten days of May (Tab. 2), then a lack of rainfall occurred during the growing season ( $-26 \%$, as compared with the 20 -yr average), reducing yields despite the three irrigations.

In this first year, the grain yields were rather low (Tab. 3), the overall average being only 8.44 $\mathrm{Mg} \mathrm{ha}{ }^{-1}$ for dry matter; CT maize yielded $16 \%$ more than NT maize, but the difference was not statistically significant. Total dry matter yield (grain + cobs + stover), although being more than $2 \mathrm{Mg} \mathrm{ha}^{-1}$ higher for the conventional compared with the no-tillage system, showed the same pattern, being statistically unaffected by tillage treatments.

$\mathrm{N}$ fertilizing effect was statistically significant at $\mathrm{P} \leq 0.01$. Grain yield in the unfertilized plots $\left(\mathrm{N}_{0}\right)$ was very low $\left(6.03 \mathrm{Mg} \mathrm{ha}^{-1}\right)$, while it increased by $46 \%$ and $74 \%$ for $\mathrm{N}_{1}$ and $\mathrm{N}_{2}$, respectively. The two fertilizing rates (250 and 300 $\mathrm{kg} \mathrm{N} \mathrm{ha-1)} \mathrm{were} \mathrm{not} \mathrm{statistically} \mathrm{different.}$

Tillage system $\times \mathrm{N}$ fertilizing interaction was not significant, although the CT- $\mathrm{N}_{2}$ sub-plots

Table 3. YEAR 2004. Dry matter yield, nitrogen uptake and apparent recovery of maize under two soil management systems and three rates of $\mathrm{N}$ fertilizing.

\begin{tabular}{|c|c|c|c|c|c|}
\hline & $\begin{array}{c}\text { Grain } \\
\text { yield } \\
\left(\mathrm{Mg} \mathrm{ha}^{-1}\right)\end{array}$ & $\begin{array}{c}\text { Total } \dagger \\
\text { yield } \\
\left(\mathrm{Mg} \mathrm{ha}^{-1}\right)\end{array}$ & $\begin{array}{c}\text { Grain } \\
\text { N uptake } \\
\left(\mathrm{kg} \mathrm{ha}^{-1}\right)\end{array}$ & $\begin{array}{c}\text { Total } \dagger \\
\mathrm{N} \text { uptake } \\
\left(\mathrm{kg} \mathrm{ha}^{-1}\right)\end{array}$ & $\begin{array}{c}\text { N Apparent } \\
\text { Recovery } \dagger \dagger \\
(\%)\end{array}$ \\
\hline Tillage system & n.s. & n.s. & n.s. & n.s. & \\
\hline NT & 7.80 & 14.22 & 95.1 & 138.6 & \\
\hline $\mathrm{CT}$ & 9.08 & 16.41 & 105.9 & 153.2 & \\
\hline $\mathbf{N}$ fertilizing & 0.01 & 0.01 & 0.001 & 0.001 & \\
\hline $\mathrm{N}_{0}$ & $6.03 \mathrm{a}$ & $12.07 \mathrm{a}$ & $61.3 \mathrm{a}$ & $91.2 \mathrm{a}$ & - \\
\hline $\mathrm{N}_{1}$ & $8.78 \mathrm{~b}$ & $15.29 \mathrm{ab}$ & $107.6 \mathrm{~b}$ & $153.8 \mathrm{~b}$ & 25 \\
\hline $\mathrm{N}_{2}^{1}$ & $10.52 \mathrm{~b}$ & $18.58 \mathrm{~b}$ & $132.5 \mathrm{~b}$ & $192.6 \mathrm{c}$ & 34 \\
\hline Interaction & n.s. & n.s. & n.s. & n.s. & \\
\hline NT-N ${ }_{0}$ & 5.48 & 11.15 & 57.9 & 87.9 & - \\
\hline NT-N & 8.90 & 15.34 & 110.6 & 157.0 & 28 \\
\hline NT-N ${ }_{2}$ & 9.04 & 16.17 & 117.0 & 170.7 & 28 \\
\hline $\mathrm{CT}^{-\mathrm{N}_{0}}$ & 6.58 & 13.00 & 64.8 & 94.4 & $\ldots$ \\
\hline $\mathrm{CT}^{-N_{1}}$ & 8.66 & 15.23 & 104.7 & 150.6 & 22 \\
\hline $\mathrm{CT}-\mathrm{N}_{2}$ & 12.00 & 21.00 & 148.1 & 214.6 & 40 \\
\hline Overall mean & 8.44 & 15.32 & 100.5 & 145.9 & \\
\hline
\end{tabular}

Within the same column, means followed by the same letter are not significantly different at $\mathrm{P} \leq 0.05$ according to LSD test; $\mathrm{n} . \mathrm{s}$. $=$ not significant.

$\dagger$ Total $=$ grain + cobs + stover

$\dagger$ Calculated as the difference between the uptake for the fertilized plots and that for the unfertilized plots, divided by the $\mathrm{N}$ applied.

NT = no-tillage $; \mathrm{CT}=$ conventional tillage

$\mathrm{N}_{0}=0 \mathrm{~kg} \mathrm{~N} \mathrm{ha}^{-1} ; \mathrm{N}_{1}=250 \mathrm{~kg} \mathrm{~N} \mathrm{ha}^{-1} ; \mathrm{N}_{2}=300 \mathrm{~kg} \mathrm{~N} \mathrm{ha}^{-1}$. 
yielded $3 \mathrm{Mg}^{-1}$ more than the NT-N ${ }_{2}$ subplots.

As was found for the yields, $\mathrm{N}$ uptakes under no-tillage management were lower than for $\mathrm{CT}$, and not significantly different. On the contrary, $\mathrm{N}$ fertilization clearly affected $\mathrm{N}$ uptake: the $\mathrm{N}_{1}$ and $\mathrm{N}_{2}$ plots removed more nitrogen compared with $\mathrm{N}_{0}$, both for grain and total uptake $(\mathrm{P} \leq 0.001)$. However, the two fertilizing levels were not statistically different for grain $\mathrm{N}$ uptake, whereas all three means were separated by LSD test for total $\mathrm{N}$ uptake.

The apparent recovery of $\mathrm{N}$ fertilizer in the whole plant was calculated as the difference between the uptake for the fertilized plots and that for the unfertilized plots, divided by the $\mathrm{N}$ applied. The apparent recovery percentage was rather low, ranging from $22 \%$ to $40 \%$, due to adverse seasonal conditions and the continued positive contribution of the soil to plant nutrition.

\section{Year 2005}

In 2005 the amount of rainfall was higher than the long-term average (Tab. 2). Compared with 2004, seasonal rainfall was $193 \mathrm{~mm}$ higher. The distribution pattern was also optimal, resulting in yield-favourable growing conditions especially for CT system, which is less water conservative than NT system. Irrigation was carried out three times. Of the three trial years, this one was the most productive (Tab. 4). The yield difference between CT and NT was not significantly different. However, significant differences appeared for $\mathrm{N}$ treatments, though rates $\mathrm{N}_{1}$ and $\mathrm{N}_{2}$ were equally effective. Interaction was again not significant, but the NT- $\mathrm{N}_{0}$ sub-plots showed a markedly improved performance compared with the first year, reaching the grain and total yields of the CT- $\mathrm{N}_{0}$ sub-plots (4.85 vs 4.75 , and 8.68 vs $8.83 \mathrm{Mg} \mathrm{ha}^{-1}$, respectively).

As regards grain and total $\mathrm{N}$ uptake, $\mathrm{CT}$ performed significantly better than NT at $\mathrm{P} \leq 5 \%$. The effect of $\mathrm{N}$ fertilizing was even more marked in this year, given that $\mathrm{N}_{1}$ and $\mathrm{N}_{2}$ plots differed at $\mathrm{P} \leq 5 \%$ level for grain $\mathrm{N}$ uptake also. These results were due to the high rainfall in the growing season, more favourable to the $\mathrm{CT}$ system. For this reason, and the depletion in $\mathrm{N}$ soil release for the $\mathrm{CT}$ plots, the apparent recovery was particularly high for CT $(65 \%)$, while it was only about $52 \%$ for NT.

Table 4. YEAR 2005. Dry matter yield, nitrogen uptake and apparent recovery of maize under two soil management systems and three rates of $\mathrm{N}$ fertilizing.

\begin{tabular}{|c|c|c|c|c|c|}
\hline & $\begin{array}{c}\text { Grain } \\
\text { yield } \\
\left(\mathrm{Mg} \mathrm{ha}^{-1}\right)\end{array}$ & $\begin{array}{c}\text { Total } \dagger \\
\text { yield } \\
\left(\mathrm{Mg} \mathrm{ha}^{-1}\right)\end{array}$ & $\begin{array}{c}\text { Grain } \\
\mathrm{N} \text { uptake } \\
\left(\mathrm{kg} \mathrm{ha}^{-1}\right)\end{array}$ & $\begin{array}{c}\text { Total } \dagger \\
\mathrm{N} \text { uptake } \\
\left(\mathrm{kg} \mathrm{ha}^{-1}\right)\end{array}$ & $\begin{array}{c}\text { N Apparent } \\
\text { Recovery } \dagger \dagger \\
(\%)\end{array}$ \\
\hline Tillage system & n.s. & n.s. & 0.05 & 0.05 & \\
\hline NT & 8.99 & 15.34 & $119.3 \mathrm{a}$ & $166.7 \mathrm{a}$ & \\
\hline $\mathrm{CT}$ & 10.52 & 17.57 & $134.4 \mathrm{~b}$ & $185.5 \mathrm{~b}$ & \\
\hline $\mathbf{N}$ fertilizing & 0.001 & 0.001 & 0.001 & 0.001 & \\
\hline $\mathbf{N}_{0}$ & $4.80 \mathrm{a}$ & 8.76 a & $49.2 \mathrm{a}$ & $69.8 \mathrm{a}$ & - \\
\hline $\mathbf{N}_{1}$ & $11.80 \mathrm{~b}$ & $19.54 \mathrm{~b}$ & $155.9 \mathrm{~b}$ & $212.4 \mathrm{~b}$ & 57 \\
\hline $\mathrm{N}_{2}$ & $12.67 \mathrm{~b}$ & $21.07 \mathrm{~b}$ & $175.4 \mathrm{c}$ & $246.1 \mathrm{c}$ & 59 \\
\hline Interaction & n.s. & n.s. & n.s. & n.s. & \\
\hline NT-N ${ }_{0}$ & 4.85 & 8.68 & 51.2 & 74.0 & - \\
\hline NT-N & 10.68 & 17.93 & 144.9 & 196.1 & 49 \\
\hline NT-N ${ }_{2}$ & 11.45 & 19.41 & 161.9 & 230.1 & 52 \\
\hline $\mathrm{CT}-\mathrm{N}_{0}$ & 4.75 & 8.83 & 47.2 & 65.6 & - \\
\hline CT-N & 12.92 & 21.15 & 167.0 & 228.7 & 65 \\
\hline $\mathrm{CT}-\mathrm{N}_{2}$ & 13.88 & 22.74 & 189.0 & 262.2 & 65 \\
\hline Overall mean & 9.76 & 16.46 & 126.9 & 176.1 & \\
\hline
\end{tabular}

Within the same column, means followed by the same letter are not significantly different at $\mathrm{P} \leq 0.05$ according to LSD test; n.s. $=$ not significant.

+ Total $=$ grain + cobs + stover

$\dagger$ Calculated as the difference between the uptake for the fertilized plots and that for the unfertilized plots, divided by the $\mathrm{N}$ applied.

NT $=$ no-tillage $; \mathrm{CT}=$ conventional tillage;

$\mathrm{N}_{0}=0 \mathrm{~kg} \mathrm{~N} \mathrm{ha-1} ; \mathrm{N}_{1}=250 \mathrm{~kg} \mathrm{~N} \mathrm{ha}^{-1} ; \mathrm{N}_{2}=300 \mathrm{~kg} \mathrm{~N} \mathrm{ha}^{-1}$. 


\section{Year 2006}

Annual rainfall in 2006 was $11 \%$ below the long-term average; however, during the growing season it was equal to the climatological average and was regularly distributed (Tab. 2). In fact, before maize planting the rainfall was 99 $\mathrm{mm}$ lower than the average. This fact favoured the NT because NT soil has a higher water retention capability compared with ploughed soil. Irrigation was carried out four times. In the third year the maize plants grown on NT plots gave a slightly higher yield than did those under CT, both in terms of grain and total dry matter, but results were not significantly different (Tab. 5). As in 2005, the effect of $\mathrm{N}$ fertilization was very clear, with significant differences between the unfertilized $\left(\mathrm{N}_{0}\right)$ and the fertilized plots $\left(\mathrm{N}_{1}\right.$ and $\left.\mathrm{N}_{2}\right)$, the latter two rates showing no difference. Interaction was not significant, but the most interesting result was that grain and total yield for NT-N $\mathrm{N}_{1}$ sub-plots were for the first time higher than for CT- $\mathrm{N}_{1}$ sub-plots $(9 \%$ and $8 \%$, respectively). The slight advantage in yield for the NT system was statistically relevant for $\mathrm{N}$ uptake $(\mathrm{P} \leq 0.05)$, both for grain and whole plant. The effect of $\mathrm{N}$ fertilization showed the same pattern as during the previous year, with a clear difference between the three rates. The apparent recovery percentage for the $\mathrm{N}_{1}$ rate was 10 percentage points higher for NT compared with CT ( $52 \%$ vs $42 \%$, respectively), demonstrating that 2006 was more favourable for no-tillage management.

\section{Three-Year Period (2004-2006)}

For the Terranova dei Passerini trial conditions, cumulated 3-yr grain and total yields were $8 \%$ lower for the no-till technique compared with those obtained under the CT system, but were not significantly different (Tab. 6). These reduced performances for NT system disagreed with the findings obtained in our previous trial, where cumulated 3-yr grain and total yields for NT maize were higher $(+8 \%$ and $+6 \%$, respectively) than those for CT maize, although not statistically different (Tabaglio and Gavazzi, 2006). This different behaviour is probably due to the soil type considered here (Ultic Haplustalf), which is low in all nutrients with the exception of available $\mathrm{P}$, leached, and quite different from the fertile soil of our previous work.

Table 5. YEAR 2006. Dry matter yield, nitrogen uptake and apparent recovery of maize under two soil management systems and three rates of $\mathrm{N}$ fertilizing.

\begin{tabular}{|c|c|c|c|c|c|}
\hline & $\begin{array}{c}\text { Grain } \\
\text { yield } \\
\left(\mathrm{Mg} \mathrm{ha}^{-1}\right)\end{array}$ & $\begin{array}{c}\text { Total } \dagger \\
\text { yield } \\
\left(\mathrm{Mg} \mathrm{ha}^{-1}\right)\end{array}$ & $\begin{array}{c}\text { Grain } \\
\mathrm{N} \text { uptake } \\
\left(\mathrm{kg} \mathrm{ha}^{-1}\right)\end{array}$ & $\begin{array}{c}\text { Total } \dagger \\
\mathrm{N} \text { uptake } \\
\left(\mathrm{kg} \mathrm{ha}^{-1}\right)\end{array}$ & $\begin{array}{c}\mathrm{N} \text { Apparent } \\
\text { Recovery } \dagger \dagger \\
(\%)\end{array}$ \\
\hline Tillage system & n.s. & n.s. & 0.05 & 0.05 & \\
\hline NT & 9.12 & 14.30 & $112.8 \mathrm{~b}$ & $145.2 \mathrm{~b}$ & \\
\hline $\mathrm{CT}$ & 8.67 & 13.83 & $106.4 \mathrm{a}$ & $136.6 \mathrm{a}$ & \\
\hline $\mathbf{N}$ fertilizing & 0.001 & 0.001 & 0.001 & 0.001 & \\
\hline $\mathrm{N}_{0}$ & $3.62 \mathrm{a}$ & $6.92 \mathrm{a}$ & $38.6 \mathrm{a}$ & $53.1 \mathrm{a}$ & - \\
\hline $\mathrm{N}_{1}^{0}$ & $11.22 \mathrm{~b}$ & $17.07 \mathrm{~b}$ & $135.6 \mathrm{~b}$ & $170.3 \mathrm{~b}$ & 47 \\
\hline $\mathrm{N}_{2}^{1}$ & $11.84 \mathrm{~b}$ & $18.21 \mathrm{~b}$ & $154.5 \mathrm{c}$ & $199.3 \mathrm{c}$ & 49 \\
\hline Interaction & n.s. & n.s. & n.s. & n.s. & \\
\hline NT-N ${ }_{0}$ & 3.75 & 6.99 & 37.5 & 52.5 & - \\
\hline NT-N & 11.73 & 17.77 & 144.3 & 182.3 & 52 \\
\hline NT-N ${ }_{2}$ & 11.88 & 18.16 & 156.4 & 200.8 & 49 \\
\hline CT-N ${ }_{0}^{2}$ & 3.49 & 6.84 & 39.7 & 53.8 & - \\
\hline CT-N & 10.72 & 16.38 & 126.8 & 158.3 & 42 \\
\hline CT-N ${ }_{2}$ & 11.80 & 18.27 & 152.6 & 197.7 & 48 \\
\hline Overall mean & 8.89 & 14.07 & 109.6 & 140.9 & \\
\hline
\end{tabular}

Within the same column, means followed by the same letter are not significantly different at $\mathrm{P} \leq 0.05$ according to LSD test; n.s. $=$ not significant.

+ Total $=$ grain + cobs + stover .

$\dagger$ Calculated as the difference between the uptake for the fertilized plots and that for the unfertilized plots, divided by the $\mathrm{N}$ applied.

NT = no-tillage $; \mathrm{CT}=$ conventional tillage

$\mathrm{N}_{0}=0 \mathrm{~kg} \mathrm{~N} \mathrm{ha}{ }^{-1} ; \mathrm{N}_{1}=250 \mathrm{~kg} \mathrm{~N} \mathrm{ha}^{-1} ; \mathrm{N}_{2}=300 \mathrm{~kg} \mathrm{~N} \mathrm{ha}^{-1}$. 
Table 6. THREE-YEAR PERIOD (2004-2006). Cumulated dry matter yield and nitrogen uptake and mean apparent recovery of maize under two soil management systems and three rates of $\mathrm{N}$ fertilizing.

\begin{tabular}{|c|c|c|c|c|c|}
\hline & $\begin{array}{c}\text { Grain } \\
\text { yield } \\
\left(\mathrm{Mg} \mathrm{ha}^{-1}\right)\end{array}$ & $\begin{array}{c}\text { Total } \dagger \\
\text { yield } \\
\left(\mathrm{Mg} \mathrm{ha}^{-1}\right)\end{array}$ & $\begin{array}{c}\text { Grain } \\
\text { N uptake } \\
\left(\mathrm{kg} \mathrm{ha}^{-1}\right)\end{array}$ & $\begin{array}{c}\text { Total } \dagger \\
\text { N uptake } \\
\left(\mathrm{kg} \mathrm{ha}^{-1}\right)\end{array}$ & $\begin{array}{c}\text { N Apparent } \\
\text { Recovery } \dagger \dagger \\
(\%)\end{array}$ \\
\hline Tillage system & n.s. & n.s. & n.s. & n.s. & \\
\hline NT & 25.91 & 43.86 & 327.2 & 450.5 & \\
\hline $\mathrm{CT}$ & 28.27 & 47.81 & 346.7 & 475.3 & \\
\hline $\mathbf{N}$ fertilizing & 0.001 & 0.001 & 0.001 & 0.001 & \\
\hline $\mathrm{N}_{0}$ & $14.45 \mathrm{a}$ & 27.75 a & $149.1 \mathrm{a}$ & $214.1 \mathrm{a}$ & - \\
\hline $\mathrm{N}_{1}^{0}$ & $31.80 \mathrm{~b}$ & $51.90 \mathrm{~b}$ & $399.1 \mathrm{~b}$ & $536.5 \mathrm{~b}$ & 43 \\
\hline $\mathrm{N}_{2}$ & $35.03 \mathrm{c}$ & $57.86 \mathrm{c}$ & $462.4 \mathrm{c}$ & $638.0 \mathrm{c}$ & 47 \\
\hline Interaction & n.s. & n.s. & n.s. & n.s. & \\
\hline NT-N ${ }_{0}$ & 14.08 & 26.82 & 146.6 & 214.4 & - \\
\hline NT-N & 31.31 & 51.04 & 399.8 & 535.4 & 43 \\
\hline NT-N & 32.37 & 53.74 & 435.3 & 601.6 & 43 \\
\hline $\mathrm{CT}-\mathrm{N}_{0}^{2}$ & 14.82 & 28.67 & 151.7 & 213.8 & - \\
\hline CT-N & 32.30 & 52.76 & 398.5 & 537.6 & 43 \\
\hline $\mathrm{CT}-\mathrm{N}_{2}$ & 37.68 & 62.01 & 489.7 & 674.5 & 51 \\
\hline Overall mean & 27.09 & 45.85 & 337.0 & 462.9 & \\
\hline
\end{tabular}

Within the same column, means followed by the same letter are not significantly different at $\mathrm{P} \leq 0.05$ according to LSD test; n.s. $=$ not significant.

+ Total $=$ grain + cobs + stover

$\dagger$ Calculated as the difference between the uptake for the fertilized plots and that for the unfertilized plots, divided by the $\mathrm{N}$ applied.

NT $=$ no-tillage; $\mathrm{CT}=$ conventional tillage;

$\mathrm{N}_{0}=0 \mathrm{~kg} \mathrm{~N} \mathrm{ha} \mathrm{k}^{-1} ; \mathrm{N}_{1}=250 \mathrm{~kg} \mathrm{~N} \mathrm{ha}^{-1} ; \mathrm{N}_{2}=300 \mathrm{~kg} \mathrm{~N} \mathrm{ha}^{-1}$

$\mathrm{N}$ fertilizing was very effective in determining grain and total yield $(\mathrm{P} \leq 0.001)$. Despite the grain yields for the $\mathrm{N}_{1}$ and $\mathrm{N}_{2}$ plots were not statistically different in any of the three years, the cumulative grain yields were separated by LSD test. On a three-year period, the increases in grain yields obtained by $\mathrm{N}$ fertilizing were $+120 \%$ and $+142 \%$ for $\mathrm{N}_{1}$ and $\mathrm{N}_{2}$, respectively.

Interaction was not significant, nevertheless some interesting considerations can be done. This trial confirmed that in the first year of the transition between tillage systems, the NT maize yield was much reduced with no "N starter" application. Indeed, the grain yield for NT- $\mathrm{N}_{0}$ subplot treatment was $17 \%$ less than for CT- $\mathrm{N}_{0}$ subplot treatment (Tab. 3). However, in the following two years NT-N $\mathrm{N}_{0}$ subplot treatments yielded $+2 \%$ (2005, Tab. 4$)$ and $+7 \%$ (2006, Tab. 5) compared with CT- $\mathrm{N}_{0}$, confirming that soil fertility restoration in NT system taking place. On a three-year period, this emerging improvement in soil conditions reduced to $5 \%$ the gap between the two subplot treatments (Tab. 6).

As regards $\mathrm{N}$ uptake, $\mathrm{N}$ fertilizing only has determined statistically significant effects $(\mathrm{P} \leq$ 0.001), following the same pattern shown each year. LSD test separates all three treatments, both for grain and total $\mathrm{N}$ uptake. The apparent recovery percentages averaged on a threeyear period were almost similar, ranging from $43 \%$ and $47 \%$ for $\mathrm{N}_{1}$ and $\mathrm{N}_{2}$, respectively.

\section{Conclusions}

Cumulative 3-yr yields in grain and total biomass of NT maize plants were $8 \%$ lower than those obtained under CT management, but not significantly different. The gap decreased progressively up to last year when NT overtook CT. The need for an $\mathrm{N}$ starter application, 30 to 40 $\mathrm{kg} \mathrm{ha}^{-1}$ in the first year of the no-tillage system was confirmed. Our data demonstrate that $\mathrm{N}$ fertilizing with 250 and $300 \mathrm{~kg} \mathrm{~N}^{-1}$ year $^{-1}$ determine statistically equal grain yields and that these extra $50 \mathrm{~kg} \mathrm{~N}$, ordinary applied by farmers of the zone, are useless, costly and negative for the sustainability of the agroecosystem. Overall, the results from the three years indicate that on an Ultic Haplustalf the conversion from a ploughed regime to mature NT conditions could be achieved over a relatively short period. 
This means that the extra $50 \mathrm{~kg} \mathrm{~N}^{-1}$ year $^{-1}$ for the $\mathrm{N}_{2}$ plots were unnecessary from an agronomic point of view, and with possible negative consequences for the sustainability of the agroecosystem.

\section{Acknowledgements}

The authors would like to thank dott. Carlo Vailati Riboni for allowing us to use his land for the trial and for his technical contribution.

\section{References}

ARPAER 2004. Progetto Aquanet. Analisi degli effetti dell'inquinamento diffuso sulle acque destinate all'uso potabile: definizione di piani di prevenzione. Progetto locale "NITRATI". Provincia di Piacenza, Piacenza.

Baker C.J., Saxton K.E., Ritchie W.R. 1996. No-tillage seeding. Science and practice. CAB International, Oxon.

Bakermans W.A.P., DeWit C.T. 1970. Crop husbandry on naturally compacted soils. Neth. J. Agric. Sci., 18:225246.

Bandel V.A., Mulford F.R., Bauer H.J. 1984. Influence of fertilizer source and placement on no-tillage maize. Fert. Issues, 1:38-43.

Borin M., Sartori L. 1995. Barley, soybean and maize production using ridge tillage, no-tillage and conventional tillage in north-east Italy. J. Agric. Engng Res. 62:229-236.

Cannell R.Q., Hawes J.D. 1994. Trends in tillage practices in relation to sustainable crop production with special reference to temperate climates. Soil Till. Res. 30:245-282.

Cassel D.K., Wagger M.G. 1996. Residue management for irrigated maize grain and silage production. Soil Till. Res., 39:101-114.

Davies D.B., Cannell R.Q. 1975. Review of experiments on reduced cultivation and direct drilling in the U.K., 1957-1974. Outlook Agric., 8:216-220.

Franzluebbers A.J., Langdale G.W., Schomberg H.H. 1999. Soil carbon, nitrogen, and aggregation in re- sponse to type and frequency of tillage. Soil Sci. Soc. Am. J., 63:349-355.

Hamza M.A., Anderson W.K. 2005. Soil compaction in cropping systems - A review of the nature, causes and possible solutions. Soil Till. Res., 82:121-145.

Phillips R.E, Phillips S.H. (eds.) 1984. No-tillage agriculture. Principles and practices. Van Nostrand Reinhold Company, New York.

Phillips R.E., Blevins R.L., Thomas G.W., Frye W.W., Phillips S.H. 1980. No-tillage agriculture. Science, 208:1108-1113.

Prasad R., Power J.F. 1991. Crop residue management. Adv. Soil Sci., 15:205-251.

Ritchie W.R., Baker C.J. 2007. Managing a No-tillage Seeding System. In: Baker C.J., Saxton K.E. (eds.): No-tillage Seeding in Conservation Agriculture, $2^{\text {nd }}$ ed., 226-235. FAO and CAB International, Rome, Italy.

Sartori L., Peruzzi A. 1994. The evolution of no-tillage in Italy: A review of the scientific literature. In: Tebrügge F. (ed.): Experience with the applicability of no-tillage crop production in the West-European Countries. Concerted action $\left(\mathrm{N}^{\circ}\right.$ AIR 3 - CT 931464), Proceedings of the EC-Workshop - I Giessen, 27-28 June 1994, Wissenschaftlicher Fachverlag, Giessen, 119-129.

Soil Survey Staff, 1996. Key to Soil Taxonomy, $7^{\text {th }}$ Ed. Natural Resources Conservation Service of the United States Department of Agriculture, Washington, DC, USA.

Sprague M.A., Triplett G.B. (eds.) 1986. No-tillage and surface tillage agriculture. The tillage revolution. John Wiley \& Sons, New York.

Tabaglio V., Gavazzi C. 2006. Yield performance of maize (Zea mays L.) cropped under conventional tillage and no-tillage in northern Italy. Agr. Med., 136:198-205.

Tabaglio V. 2007. Mais. In: Pisante M. (ed.): Agricoltura blu - La via italiana dell'agricoltura conservativa, 91102. Edagricole, Bologna.

Toderi G., Bonari E. 1986. Lavorazioni del terreno: aspetti agronomici. II. Lavorazioni e pianta coltivata. Riv. Agron., 20:106-133.

Uri N.D. 1999. The use of no till farming in U.S. agriculture: farmers' perceptions versus reality. J. Sustain. Agr., 15:5-17. 